\title{
The Analysis of the Behavioral Problems of the Pre-school Children and of the Mother-Child Relation $^{1}$
}

\author{
Büşra Kartal ${ }^{2}$
}

\begin{abstract}
This research is done in order to examine the behavioral problems that are seen in the pre-school children and the relation between mother and child. The study is prepared according to the relational screening model. The population of the study is the children that are enrolled in the pre-school institutes and kindergartens based in the central region of the providence of Kutahya as well as the parents of these children. According to the results of the study and based on the Scale of the Relation between Parents and the Child, there is no differentiation due to the age of mother and her employment status, but it is observed that there is a differentiation due to mother's educational status. In both the extrinsic and intrinsic behaviors of the child, there is a differentiation based on the age of the mother as well as her educational status. In the same way, the age and the gender of the child plays some role in the differentiation of the extrinsic and intrinsic behaviors of the child.
\end{abstract}

Keywords: Mother child relationship, behavior problems, pre-school education.

\section{Introduction}

The main goals of families and educators are to train healthy, happy and successful childreen. With this opinion that it is to train childreen who can adopt the needs of their period, aware of the development of physical and mental health (Aydoğan \& Gültekin Akduman, 2016). The psychological well-being of individuals depends largely on their childhood lives (Sargın, 2001). Behavioral disorders seen in this period have different and complex causes. Family and other environmental conditions are known to be the leading ones. Therefore, in order to eliminate and treat non-compliances, the child should be handled together with his / her environment (Bakırcığlu, 2007). The first person after the child is born interacts with and the closest one is mother (Avşaroğlu, 2012). Mom; who undertakes and fulfills all the needs and responsibilities of the child, from the birth of the child, to the care, education and health. (Alisinanoğlu, 2003). The mother's mental health plays a major role in establishing a healthy motherchild relationship. The factors such as the mother's inability to receive enough attention from her husband, an unhappy marriage, the family's economic difficulties (Yavuzer, 1999), parents' attitudes, mother's age, educational status, working status, gender of the child affect mother-child communication (Tezel Şahin, 2014). These and other reasons are thought to cause children to exhibit behavioral problems.

\footnotetext{
${ }^{1}$ This article is produced by first author's master thesis, under supervision of second author ${ }^{2}$ MA, MEB, Turkey, busra.kartal@hotmail.com, ORCID: https://orcid.org/0000-0002-6387-371X

3 Dr, Kutahya Dumlupınar University, Faculty of Education, Turkey, murat.bartan@dpu.edu.tr, ORCID: https://orcid.org/0000-0003-2947-5643
} 
Adaptation and behavioral problems are called negative reactions that occur as a result of the natural difficulties brought about by the change and development that lasts throughout life (Kılıçarslan, 2006). He stated that children who try to draw attention with behavior problems are unnoticed and stressed children and exhibit these negative behaviors more with the negative reactions they receive from other people (Wolff, 2009). Behavioral disorder may occur due to factors such as genetic background, inconsistent family attitude, exposure to physical punishments, stressful family environment, having bad habits, and low socioeconomic level (Rathus, 2006). Childhood behavioral problems are divided into two groups by researchers as outward oriented and inward oriented (Campbell, 1995). Outward oriented behavior problems; destructive, damaging, dangerous, incompatible and aggressive behavior. For this reason, the person is in harm both himself/herself and his / her around (Merrell, 2003). These behaviors seen in childhood and adolescence are weak impulse control, defiance, destructive, hyperactive, aggressive, antisocial or criminal behaviors (Bailey et al., 2009).

Inward oriented behavior problems are behaviors that include anxiety, depression, and somatic complaints. Problems within the self are inherently more confidential and therefore more difficult to detect (Wilmshurst, 2005). Despair, alienation from social environment and negative self-perception are common in introverted behavior problems (Yüksek Usta, 2014). These behaviors seen in childhood and adolescence are behavioral problems such as introversion, anxiety, fear, psychosomatic symptoms, depression (Bailey et al., 2009). The causes of behavioral problems seen in preschool period have been handled by many researchers in different aspects. When the researches were examined, it was concluded that it would be healthier to evaluate the child together with the family, environment and family relations-environment in order to identify the behavioral problems seen in children (Tok, 2001).

When the field literature is examined by the pre-school children and their families, it is seen that the problem behaviors (Çetintaş, 2015; Dursun, 2010; Eratay, 2011; Kanlıkılıçer, 2005; Karg1 \& Erkan, 2004; Kesicioğlu \& Alisinanoğlu, 2010; Kılıç, 2016; Köyceğiz, 2017; Kurt, 2015; Livanage et al., 2014; Olcay, 2008; Özbey \& Alisinanoğlu, 2009; Profeta, 2002; Seven, 2007; Sehirli, 2007; Taner Derman \& Başal, 2013; Tarkoçin \& Tuzcuoğlu, 2014; Turan Güven, 2018; Uyanık Balat et al., 2008; Yaşar Ekici, 2013; Yaşar Ekici, 2014), and the studies investigating the relationship between mother and child (Alpgan, 2017; Aslan, 2018; Bartan \& Tezel Şahin, 2012; Çakıc1, 2006; Driscoll \& Pianta, 2011; Kök, 2011; Respect, 2011; Sayg1 \& Uyanık Balat, 2013; Selimoğlu, 2014; Yüksek Usta, 2014). In this context, this study was conducted based on the important and major role of the mother in children's behaviors; the aim of this study was to determine the behavioral problems observed by the mothers who had preschool children and the relationship between the mothers and their children.

\section{Method}

The aim of this research was to investigate the relationship between behavioral problems in pre-school children and mother-child. Therefore, the research was prepared in accordance with the relational screening model. Relational studies are the studies that are used to see the relationship between two or more variables and the variables do not affect each other, where there is a possibility of explaining the relationships between the variables and predicting the results (Tekbıyık, 2015). 


\section{Participants}

The universe of the research is the children and mothers of the children who were educated in independent kindergartens and kindergartens affiliated to the Ministry of National Education in the city center of Kütahya. Random sampling method was used for the research. In this context, the study was conducted with 327 children who received pre-school education in 4 independent kindergartens and 3 primary schools in different regions of the Ministry of National Education in Kütahya city center and the mothers of 327 children who voluntarily participated in the study.

\section{Table 1}

Informations on Participating Mothers and Children

\begin{tabular}{lcclccc}
\hline Working Status of the Mother & $\mathrm{N}$ & $\%$ & Gender of the Child & $\mathrm{N}$ & $\%$ \\
\hline Working & 62 & 19.0 & Girl & 192 & 58.7 \\
Not Working & 265 & 81.0 & Male & 135 & 41.3 \\
Total & 327 & 100.0 & Total & 327 & 100.0 \\
\hline Age of Mother & $\mathrm{N}$ & $\%$ & Age of Child & $\mathrm{n}$ & $\%$ \\
\hline 20-29 & 40 & 12.2 & 4 & 56 & 17.1 \\
$30-39$ & 238 & 72.8 & 5 & 113 & 34.6 \\
40 and Older & 49 & 15.0 & 6 & 158 & 48.3 \\
Total & 327 & 100.0 & Total & 327 & 100.0 \\
\hline Education Level of Mother & $\mathrm{N}$ & $\%$ & & $\mathrm{~N}$ & $\%$ \\
\hline Primary School Graduate & 45 & 13.8 & High School Graduate & 106 & 32.4 \\
Secondary School Graduate & 102 & 31.2 & Graduated from a Universty & 74 & 22.6 \\
& & & Total & 327 & 100.0 \\
\hline
\end{tabular}

When the working conditions of the mothers who participated in the study were examined; $62(19 \%)$ of the mothers stated that they were working and $265(81 \%)$ stated that they were not working. $238(72.8 \%)$ of the mothers were in the 30-39 age range. In addition, 40 mothers (12.2\%) were in the 20-29 age range, while $49(15 \%)$ mothers were 40 years and older. When the education levels of the mothers were examined; 45 mothers $(13.8 \%)$ are primary school graduates, 102 mothers $(31.2 \%)$ are secondary school, 106 mothers (32.4\%) are high school graduates and 74 mothers (22.6\%) are university graduates. When Table 1 is examined; 192 girls and 135 children were boys. 56 children at the age of 4, 113 children at the age of 5 and 158 children at the age of 6 participated in the study. 


\section{Data Collection Tools}

\section{Personal Information Form}

In order to get detailed information about the participants, it is a form that includes questions such as the age, gender, age of the mother, education level, working status, coexistence or separation of the parents. Problem Behavior Scale: It is the scale that it was developed by Kenneth W. Merrell (1994) and then it was revised in 2003 and it was composed of 42 items aiming to determine problem behaviors. It is a scale consisting of two sub-dimensions adapted to Turkish by Fazlioglu et al. (2011), and Cronbach's Alpha reliability coefficients were found to be higher than .70 .

\section{Child-Parent Relationship Scale}

It was developed by Pianta in 1992. The Child-Parent Relationship Scale was named as RS CPRS '(ChildParent-Relationship Scale). The scale, which aims to evaluate the relationship between children and their parents based on the perception of the parent, is a 24 items, 5-point Likert-type scale that can be answered in about 15 minutes. Akgün and Yeşilyaprak (2008) adapted the Turkish version. At the result of the analyzes, the complete of the scale is enough for the reliability of the scale and conflict subscale were calculated as .98 for the test-retest reliability coefficient, .96 for the positive relationship dimension subscale, and .96 for the total score. The internal consistency coefficients (Cronbach's alpha) of the scale were .85 for the conflict-size subscale; the positive dimension subscale was .73 and .73 for the total. After Spearman Brown correction, the correlation between the two halves of the test was calculated as .84, .73 and.72 respectively. The scale consists of two sub-dimensions. These are referred to as Conflict and Positive Relationship.

\section{Data Analysis}

Before the data analysis stage, Tabachnick and Fidell (2007) suggested that the data was cleaned in order. In the first step, the data was carefully reviewed and then descriptive statistical analyzes were applied to test whether the minimum and maximum values of the scales used in the research were within the required limits. Analysis results show that all the values entered are within the lower and upper values. In the second step, skewness and kurtosis values were examined to determine whether the variables discussed in the study met the normality. The results show that all variables are within the appropriate limits. First, for $\mathrm{df}=2, \mathrm{p}<.001$ calculated at 13.82 Mahalanobis distance of (Mahalanobis distance) on exceeding any Although not participating conflict variable and positive relationships variable $Z$ score \pm 3:29 boundaries have been seen 2 participants and said the participants in the analysis it is excluded from the data set to be executed. In the fourth step, MANOVA was mostly preferred to examine the differences between the groups. However, when the distribution of mothers according to age ranges is examined, it is seen that mothers between the ages of 20-29 constitute $12.2 \%$ of the sample and $15 \%$ of mothers aged 40 years and over. However, the mothers in the 30-39 age range constitute $72.8 \%$ of the sample. Therefore, it is seen that there are significant differences between the rates of participants in the 30-39 age group and the rates of participants in other groups. For this reason, Kruksal-Wallis test, one of the nonparametric tests, was used in the analysis in which the age range of the mother was used as an independent variable. In addition, only 19\% of the mothers reported that they were working, while $81 \%$ reported that they were not. Significant differences between the proportions of the participants in the groups are also observed here. For this reason, Mann Whitney -U test, one of the nonparametric tests, was used in the analysis in which the working status of the mother 
was used as an independent variable. In the last stage of the analysis, Q-Q graphs were examined to check whether the linearity condition was satisfied. The results showed that the variables were linear. As a result of these operations, the data set was made ready for analysis.

\section{Findings}

In this part of the research, the results of the data analyzed are presented in tables. Descriptive statistics of measurement tools in the research the lowest and highest values, means and standard deviations of the scales included in the study are presented in Table 2.

\section{Table 2}

The lowest and highest values of the scales in the study. Means and Standard Deviations

\begin{tabular}{llllll}
\hline & $\mathrm{N}$ & Lowest Values & Highest Values & Mean & SD \\
\hline Conflict & 327 & 1.15 & 4.00 & 2.18 & .60 \\
Positive Relationship & 327 & 3.00 & 5.00 & 4.32 & .42 \\
Outward Orientation Problem & 327 & .07 & 1.89 & .95 & .38 \\
Inward Orientation Problem & 327 & .13 & 1.73 & .97 & .37 \\
\hline
\end{tabular}

When Table 2 is examined; the highest scores reported by mothers belong to the positive relationship variable. In addition, the mean of outward and inward problems indicates that these problems are experienced at a very low level.

Table 3.

Mean and Standard Deviation of Conflict and Positive Relationship Perception by Age Range of Mothers

\begin{tabular}{|c|c|c|c|c|c|}
\hline Variables & $\begin{array}{l}\text { Age range of } \\
\text { mothers }\end{array}$ & $\mathrm{n}$ & $\begin{array}{c}\text { Average of } \\
\text { groups }\end{array}$ & Mean & SD \\
\hline \multirow[t]{4}{*}{ Conflict } & $20-29$ & 40 & 186.90 & 2.33 & .65 \\
\hline & $30-39$ & 238 & 162.01 & 2.17 & .61 \\
\hline & 40 and Above & 49 & 154.95 & 2.13 & .56 \\
\hline & Total & 327 & & 2.18 & .61 \\
\hline \multirow{4}{*}{$\begin{array}{l}\text { Positive } \\
\text { Relationship }\end{array}$} & $20-29$ & 40 & 182.05 & 4.41 & .41 \\
\hline & $30-39$ & 238 & 163.10 & 4.31 & .43 \\
\hline & 40 and Above & 49 & 153.62 & 4.28 & .42 \\
\hline & Total & 327 & & 4.32 & .42 \\
\hline
\end{tabular}


When Table 3 is examined; Kruksal-Wallis test was performed to examine whether there is a difference in the mother's perception of conflict and positive relationship depending on the age range of the mother. The results showed that there was no difference in the perception of both conflict and positive relationship depending on the age range of the mother $(p>.05)$.

\section{Table 4}

Mean and Standard Deviation of Conflict and Positive Relationship Perception According to Education Level of Mothers

\begin{tabular}{lllll}
\hline Variables & Eeducation level & $\mathrm{n}$ & Mean & SD \\
\hline & Primary School & 45 & 2.20 & .74 \\
Middle School & 102 & 2.33 & .60 & .58 \\
Conflict & High School & 106 & 2.18 & .53 \\
& University & 74 & 1.98 & .61 \\
\hline Total & Primary School & 45 & 2.18 & .47 \\
Positive Relationship & Middle School & 102 & 4.28 & .41 \\
& High School & 106 & 4.30 & .42 \\
& University & 74 & 4.28 & .42 \\
\hline
\end{tabular}

When Table 4 is examined, one-way MANOVA was conducted to examine whether there is a difference in the mother's perception of conflict and positive relationship according to the education level of the mother. The results of the Box'M test show that the covariance matrices of the groups are homogeneous $(p>$.05). Levene test results showed that the variances of the variables were homogeneous between the groups $(p>.05)$. The results obtained from MANOVA show that the differentiation depending on the education level of the mother is significant, Wilks ' $\lambda=.94, F(6,644)=3.63, p<.01, \eta^{2}=.03$. In further analysis to determine which dependent variable is the main effect, it is seen that there are differences in the perception of conflict depending on the education level of the mother, $F(3,1.74)=4.90, p<.01, \eta^{2}=$ .04. As can be seen in Table 4 it is seen that the conflict level reported by middle school mothers is significantly higher than the conflict level reported by university mothers. 


\section{Table 5}

Mean and Standard Deviation of Conflict and Positive Relationship Perception by Mothers' Working Conditions

\begin{tabular}{|c|c|c|c|c|c|c|c|}
\hline Variables & $\begin{array}{l}\text { Working } \\
\text { Status }\end{array}$ & $\mathrm{n}$ & $\begin{array}{l}\text { Average of } \\
\text { Groups }\end{array}$ & $\begin{array}{l}\text { Sum of Rank } \\
\text { Averages }\end{array}$ & Mean & SD & Median \\
\hline \multirow{4}{*}{ Conflict } & Working & 62 & 144.77 & 8976.00 & 2.10 & .72 & 1.81 \\
\hline & Not & 265 & 168.50 & 44652.00 & 2.20 & .58 & 2.15 \\
\hline & Working & & & & & & \\
\hline & Total & 327 & & & 2.18 & .61 & \\
\hline \multirow{4}{*}{$\begin{array}{l}\text { Positive } \\
\text { relationship }\end{array}$} & Working & 62 & 170.64 & 10579.50 & 4.34 & .46 & 4.45 \\
\hline & Not & 265 & 162.45 & 43048.50 & 4.31 & .42 & 4.40 \\
\hline & Working & & & & & & \\
\hline & Total & 327 & & & 4.32 & .42 & \\
\hline
\end{tabular}

When Table 5 was examined, Mann-Whitney $U$ test was used to examine whether there is a difference in the mother's perception of conflict and positive relationship according to the working status of the mother. The results show that there is no significant difference according to the working status of the mother $(p>.05)$.

\section{Table 6}

Mean and Standard Deviation Values of Children's Perception of Conflict and Positive Relationship by Gender of Children

\begin{tabular}{lllll}
\hline & Gender of the Child & $\mathrm{n}$ & Mean & SD \\
\hline Conflict & Girl & 192 & 2.20 & .62 \\
& Male & 135 & 2.16 & .58 \\
& Total & 327 & 2.18 & .61 \\
\hline Positive & Girl & 192 & 4.37 & .38 \\
relationship & Male & 135 & 4.24 & .47 \\
& Total & 327 & 4.32 & .42 \\
\hline
\end{tabular}

When Table 6 is analyzed, one-way MANOVA was conducted to examine whether conflict and positive relationship perception differed according to the gender of the child. The results of Box'M test showed that the covariance matrices of the groups were not homogeneous $(p<.05)$. Levene test results showed that the variances for the conflict variable were homogeneous between the groups $(p>.05)$. For the positive correlation variable, the variances were not homogeneous between the groups $(p<.05)$. 
MANOVA results show that differentiation is significant according to the gender of the child. Pillai's Trace $=.31, F(2,324)=5.20, p<.01, \eta^{2}=.03$. In the advanced analysis to determine which dependent variable is the main effect, there is a significant difference in the perception of positive relationship. $F$ ( 1 , 1.39) $=7.89, p<.01, \eta^{2}=.02$. As can be seen from Table 6, mothers of girls reported more positive relationships than mothers of boys.

\section{Table 7}

Mean and Standard Deviation of Conflict and Positive Relationship Perception by Age of Children

\begin{tabular}{|c|c|c|c|c|}
\hline & Age of Child & $\mathrm{n}$ & Mean & SD \\
\hline \multirow{4}{*}{ Conflict } & 4 & 56 & 2.07 & .57 \\
\hline & 5 & 113 & 2.28 & .62 \\
\hline & 6 & 158 & 2.16 & .60 \\
\hline & Total & 327 & 2.18 & .61 \\
\hline \multirow{4}{*}{ Positive Relationship } & 4 & 56 & 4.38 & .35 \\
\hline & 5 & 113 & 4.32 & .44 \\
\hline & 6 & 158 & 4.29 & .44 \\
\hline & Total & 327 & 4.32 & .42 \\
\hline
\end{tabular}

When Table 7 is examined; One-way MANOVA was conducted to examine whether the perception of conflict and positive relationship differed according to the age of the child. The results show that there is no significant difference between different age groups $(p>.05)$.

\section{Table 8}

Mean and Standard Deviation Values of Problem Behaviors exhibited by Age Range of Mothers

\begin{tabular}{llcccc}
\hline & $\begin{array}{l}\text { Age Range } \\
\text { of Mothers }\end{array}$ & $\mathrm{n}$ & $\begin{array}{c}\text { Average of } \\
\text { Groups }\end{array}$ & Mean & SD \\
\hline $\begin{array}{l}\text { Outward } \\
\text { Orientation } \\
\text { Problems }\end{array}$ & $20-29$ & 40 & 172.14 & .99 & .41 \\
& $30-39$ & 238 & 171.59 & .99 & .38 \\
& $40+$ & 49 & 120.49 & .77 & .33 \\
\hline $\begin{array}{l}\text { Inward } \\
\text { Orientation }\end{array}$ & $20-29$ & 327 & & .95 & .38 \\
Problems & $30-39$ & 40 & 143.80 & .99 & .38 \\
& $40+$ & 238 & 169.19 & .92 & .38 \\
\hline
\end{tabular}


When Table 8 is examined, Kruksal-Wallis test was performed to examine whether there is a difference in the behavior of children depending on the age range of the mother. The results show that there is a differentiation depending on the age range of the mother in externalizing problems. $\chi^{2}(2)=12.24 . p<.01$. Then, a series of Mann Whitney-U tests were performed to determine the difference between the groups and the Bonferroni correction was performed and the critical value was taken as $p<.017$. When the results were examined, it was seen that mothers aged 40 and older reported less externalizing problems than mothers aged 20-29 and 30-39 years; $z=-2.50 . p<.01 . z=-3.46$, respectively $(p<.01)$.

\section{Table 9}

Mean and Standard Deviation Values of Problem Behaviors exhibited by Education Level of Mothers

\begin{tabular}{lllll}
\hline Variables & $\begin{array}{l}\text { Level of } \\
\text { education }\end{array}$ & $\mathrm{n}$ & Mean & SD \\
\hline $\begin{array}{l}\text { Outward Orientation } \\
\text { Problems }\end{array}$ & Primary School & 45 & .90 & .39 \\
& Middle School & 102 & .91 & .38 \\
& High School & 106 & 1.00 & .34 \\
& University & 74 & .97 & .33 \\
\hline $\begin{array}{l}\text { Inward Orientation } \\
\text { Problems }\end{array}$ & Primary School & 45 & .95 & .39 \\
& Middle School & 102 & .94 & .41 \\
& High School & 106 & .89 & .32 \\
\hline
\end{tabular}

When Table 9 is examined; one-way MANOVA was conducted to examine whether there is a difference in the behavior of the child depending on the educational status of the mother. The results of Box'M test showed that the covariance matrices of the groups were not homogeneous $(p<.05)$. Levene test results showed that the variance for the inward variable was homogeneous between the groups ( $\mathrm{p}>.05)$. For the outward variable, the variances were not homogeneous between the groups $(p<.05)$.

MANOVA results show that there is a meaningful differentiation depending on the education level of the mother, Pillai's Trace $=.12, F(6.646)=7.05, p<.001 . \eta^{2}=.06$. In the advanced analysis to determine which dependent variable is the main effect, it is seen that there is a significant differentiation in inward orientation problems. $F(3,1.04)=7.94, p<.001, \eta^{2}=.07$ As can be seen from Table 9, middle school graduates reported higher internalization problems than both high school graduates and university graduates. 
Table 10

Mean and Standard Deviation Values of Problem Behaviors exhibited by Working Status of Mothers

\begin{tabular}{llllllll}
\hline Variables & Working Status & $\mathrm{n}$ & $\begin{array}{l}\text { Average } \\
\text { of } \\
\text { Groups }\end{array}$ & $\begin{array}{l}\text { Sum of } \\
\text { Rank } \\
\text { Averages }\end{array}$ & Mean & SD & Median \\
\hline $\begin{array}{l}\text { Outward } \\
\text { Orientation }\end{array}$ & Working & 62 & 146.15 & 9061.00 & .88 & .35 & .91 \\
Problems & Not Working & 265 & 168.18 & 44567.00 & .97 & .39 & .96 \\
& Total & 327 & & & .95 & .38 & \\
\hline $\begin{array}{l}\text { Inward } \\
\text { Orientation }\end{array}$ & Working & 62 & 162.15 & 10053.00 & .95 & .36 & .97 \\
Problems & Not Working & 265 & 164.43 & 43575.00 & .97 & .38 & 1.00 \\
& Total & 327 & & & .97 & .37 & \\
\hline
\end{tabular}

When Table 10 is examined; Mann-Whitney $U$ test was used to investigate whether there is a difference in the behavior of the child depending on the working status of the mother. The results show that there is no significant difference between the children of working and non-working mothers ( $p>.05)$.

\section{Table 11}

Average and Standard Deviation Values of Problem Behaviors Displayed by Gender of Children

\begin{tabular}{llccc}
\hline Variables & Gender of the child & $\mathrm{n}$ & Mean & SD \\
\hline Outward Orientation Problems & Girl & 192 & .97 & .40 \\
& Male & 135 & .94 & .36 \\
& Total & 327 & .95 & .38 \\
\hline Inward Orientation Problems & Girl & 192 & 1.01 & .39 \\
& Male & 135 & .91 & .34 \\
& Total & 327 & .97 & .37 \\
\hline
\end{tabular}

When Table 11 is examined; One-way MANOVA was conducted to investigate whether there is a difference in the child's problem behaviors depending on the gender of the child. The results of Box'M test showed that the covariance matrices of the groups were not homogeneous $(p<.05)$. Levene test results showed that the variances were homogeneous between the groups for both inward and outward variables $(p>.05)$. For the outward variable, the variances were not homogeneous between the groups ( $p$ $<.05)$. MANOVA results show that there is a significant differentiation depending on the gender of the child. Pilla's Trace $=.20, F(2,324)=3.28, p<.05, \eta^{2}=.02$ in the further analysis to determine which 
dependent variable is the main effect, there is a significant difference in inward orientation problems. $F$ $(1,0.88)=6.42, p<.05, \eta^{2}=.02$.

\section{Table 12}

The mean and Standard Deviation Values of the Problem Behaviors Exhibited by the Children According to the Age of the Children

\begin{tabular}{|c|c|c|c|c|}
\hline Variables & Age of children & Mean & $\mathrm{n}$ & SD \\
\hline \multirow[t]{4}{*}{ Outward Orientation Problems } & 4 & 1.00 & 56 & .32 \\
\hline & 5 & 1.11 & 113 & .39 \\
\hline & 6 & .82 & 158 & .35 \\
\hline & Total & .96 & 327 & .38 \\
\hline \multirow[t]{4}{*}{ Inward Orientation Problems } & 4 & .85 & 56 & .34 \\
\hline & 5 & .94 & 113 & .29 \\
\hline & 6 & 1.03 & 158 & .42 \\
\hline & Total & .97 & 327 & .37 \\
\hline
\end{tabular}

When Table 12 is examined; One-way MANOVA was conducted to investigate whether there is a difference in the child's problem behaviors depending on the age of the child. The results of Box'M test showed that the covariance matrices of the groups were not homogeneous $(p<.05)$. Levene test results showed that the variances were homogeneous between the groups for outward orientation $(p>.05)$. For the inward variable, the variances were not homogeneous between the groups $(p<.05)$. The results show that there is a significant differentiation depending on the age of the child, Pilla's Trace $=.22, F(2,648)=$ $120.45, p<.001, \eta^{2}=.11$. In the advanced analysis to determine which dependent variable is the main effect, it is seen that there is a significant difference in both internalizing problems and externalizing problems; $F(2.2 .85)=22.02, p<.001, \eta^{2}=.12$, respectively; $F(2,0.75)=5.49, p<.01, \eta^{2}=.03$. As can be seen from Table 12, children 4 and 5 years old. It has more externalizing problems than 6 year old children. In addition, six-year-old children have more internalizing problems than four-year-old children.

\section{Table 13}

Correlations between variables

\begin{tabular}{lcccc}
\hline Variables & 1 & 2 & 3 & 4 \\
\hline Conflict & 1 & & \\
Positive Relationship & $-.28^{* * *}$ & 1 & \\
Outward Orientation Problems & $.26^{* * *}$ & -.01 & 1 & 1 \\
Inward Orientation Problems & $.31^{* * *}$ & -.05 & $.40^{* * *}$ & 1 \\
\hline
\end{tabular}

${ }^{* * *} p<.001$ 
When Table 13 is examined; there is also a positive relationship between conflict, internalizing problems and externalizing problems.

\section{Table 14}

Regression Analysis of the Contribution of Conflict and Positive Relationship to Prediction of Inward and Outward Behavior

\begin{tabular}{llllll}
\hline Inward Behaviors & & & & & \\
Variables & $R^{2}$ & $B$ & Standard Error & $B$ & $t$ \\
\hline Conflict & .10 & .19 & .03 & .32 & $5.73^{* * *}$ \\
Positive Relationship & & .03 & .05 & .04 & 1.68 \\
\hline Outward Behaviors & & & & & \\
Variables & $R^{2}$ & $B$ & Standard Error & $B$ & $t$ \\
\hline Conflict & .07 & .18 & .40 & .28 & $4.99^{* * *}$ \\
Positive Relationship & & .07 & .50 & .07 & 1.32 \\
\hline
\end{tabular}

When Table 14 is examined; two separate regression analyzes were conducted to investigate the extent to which conflict and positive relationship predicted outward and inward behavior. In the regression analyzes conducted, the predictive variables of conflict and positive relationships were predictor variables while outward and inward behaviors were predicted variables. When the results of the first regression analysis are examined, it is seen that the conflict positively predicts the inward behaviors. $\beta=$ $.32, p<.001$. However, positive relationship has no significant predictive effect on invard behaviors, $p>$ .05. The results of the second regression analysis showed that the conflict positively predicted the outward behavior. $\beta=.28, p<.001$. However, there is no significant predictive effect of positive relationship on outward behaviors $(p>.05)$.

\section{Discussion}

The results of the study conducted to examine the relationship between the relationship between mothers of preschool children and behavioral disorders and the relationship between the literature and the literature are given below. When the scores obtained from the child-parent relationship scale were examined, it was observed that there was no difference in the conflict and positive relationship subdimensions of the scale depending on the age range of the mother. When the other studies carried out with the same measurement tool; Alpgan (2017), Çakıcı (2006), Kök (2017) and Selimoğlu (2014) reported that the age of the mother did not cause any differentiation in the mother-child relationship by reaching similar results. These results coincide with the results of our study. In the researches examining the relationship between mother and child with different measurement tools, when the results regarding the age of mothers are examined; Respect (2011), Aslan (2018) showed similar results in their research. When the mother's perception of conflict and positive relationship is differentiated depending on the educational status; it was observed that there were differences in the perception of both conflict 
and positive relationship depending on the education level of the mother and the conflict level of middle school graduate mothers was significantly higher than the conflict level of university graduate mothers. When the other studies carried out with the same measurement tool, similar results are observed in the study of Çakıcı (2006), Kök (2017) and Selimoğlu (2014). In addition, in the researches of Yüksek Usta (2014), it is seen that mothers' education levels make a significant difference in motherchild relationship. In the researches examining the relationship between mother and child with different measurement tools, when the results of mothers' education levels are examined; Aslan (2018), Sayg1 (2011), Sayg1 and Uyanık Balat (2013) have reached similar results in their research.

When the mother's perception of conflict and positive relationship is examined according to whether or not the mothers work status; it was observed that there was no difference in both perception of conflict and positive relationship depending on whether the mother worked or not. When the other studies conducted by Alpgan (2017), Kök (2017), and Yüksek Usta (2014), with the same measurement tool are examined, it is seen that there is no difference in the relationship between mother and child depending on whether the mother works or not. In the researches examining the relationship between mother and child with different measurement tools, when the results related to mothers' working status are examined; Aslan (2018) did not find any difference in his research, while Sayg1 (2011) found a difference in his research. This difference is believed to result from the measurement tools When the mother's perception of conflict and positive relationship is examined, it is examined whether there is a difference depending on the child's gender; it was observed that there was a difference in the perception of conflict and positive relationship according to the gender of the child and the mothers of the girls reported more positive relationships than the mothers of the boys. When the other studies carried out with the same measurement tool; Kök (2017) concluded that there was no difference in the relationship between mother and child according to the gender of the child. The reason for this is thought to be the sample distribution. In the studies examining the mother-child relationship with different measurement tools, when the results regarding the gender status of the children are examined; Aslan (2018) and Driscoll and Pianta (2011), in their research, conclude that the gender of children makes a difference. When the mother's perception of conflict and positive relationship is examined whether there is a differentiation according to the age of the child; both conflict and positive relationship perception did not differ according to the age of the child. When the other studies carried out with the same measurement tool; Alpgan (2017) revealed in his study that there is no differentiation in the mother-child relationship according to the age of the child. In the researches examining the relationship between mother and child with different measurement tools, when the results regarding the age status of the children are examined; Aslan (2018) did not find any difference in his research; Sayg1 (2011) found a difference in his research. This difference is thought to be due to the measurement tool.

When the problem behaviors exhibited by children is examined according to the age of their mothers; it was observed that there was a difference in the outward and inward behaviors of the children depending on the age range of the mother, and that mothers aged 40 and over reported less outward problems than mothers aged 20-29 and 30-39 years. When the other studies carried out with the same measurement tool; Yaşar Ekici (2014) concluded that there is no difference between the problem behaviors of children and the age of their mothers. The reason for this is thought to be related to the sample. When the results related to the age of the mother are examined in researches conducted with different measurement tools related to problem behaviors; Kanlıkılıçer (2005), Olcay (2008), and Dursun 
(2010) concluded that the age of the mother makes a significant difference in their research. In their studies, Yaşar Ekici (2013) and Çetintaş (2015) revealed that the age of the mother did not make a significant difference. The reason for this is thought to be due to the fact that the researches were conducted with different measurement tools.

When the relationship between children's problem behaviors and mother's education level is examined; Mothers with high school and university graduates reported higher rates of internalization problems than the mothers of high school and university graduates. When the other studies carried out with the same measurement tool, similar results are also observed in the studies of Yaşar Ekici (2014) and Köyceğiz (2017). When the results related to the education level of the mother are examined in the researches made with different measurement tools related to problem behaviors; Yaşar Ekici (2013), Çetintaş (2015) reached similar results in the surveys while Şehirli (2007), Uyanık Balat et al. (2008) Eratay (2011) concluded that mothers' educational status was related to problem behaviors. Kesicioğlu and Alisinanoğlu (2010) Tarkoçin and Tuzcuoğlu (2014) found no significant relationship between mothers' educational status and problem behaviors. This difference is thought to result from the selected samples. When the problem behaviors exhibited by the children are examined, it was observed that there was no difference in both outward and inward behaviors exhibited by children depending on the working status of the mother. When the other studies carried out with the same measurement tool are examined, similar results are also seen in the esearch of Yaşar Ekici (2014). When the results related to the working status of the mother are analyzed in different researches about problem behaviors; Şehirli (2007), Olcay (2008), and Yaşar Ekici (2013) have reached the same results with the results of their research. Seven (2007) and Çetintaş (2015) found a relationship between problem behaviors and working status of the mother.

When the problem behaviors exhibited by the children is differentiated depending on the gender of the child; it was observed that there was a difference in both outward and inward behaviors of the children depending on the gender of the child and the mothers of the girls reported a higher rate of internalizing problems. When the other studies carried out with the same measurement tool, similar results are also seen in their research of Kurt (2015), Özbey (2009) and Yaşar Ekici (2014). Turan Güven (2018) stated that there was no significant difference according to gender.

When the results related to the gender status of the child are analyzed in different researches about problem behaviors; Kargı and Erkan (2004), Kanlıkılıçer (2005), Şehirli (2007), Seven (2007), Olcay (2008) Uyanık Balat et al. (2008), Özbey and Alisinanoğlu (2009), Dursun (2010), Tarkoçin and Tuzcuoğlu (Turkish). 2014), Çetintaş (2015), Taner Derman and Başal (2013), and Kılıç (2016) found a relationship between child's gender and problem behaviors. In foreign studies, Profeta (2002) examined the relationship between child's behavior problems and perception of parental conflict, and Livanage et al. (2003) examined the relationship between the activities of mothers with preschool children and the behavioral problems seen in children.

When the problem behaviors exhibited by the children, whether there is a difference depending on the age of the child; It was observed that both the outward and inward behaviors of the children exhibited more externalizing problems than the 6-year-old children with 4 and 5-year-old children with a differentiation depending on the age of the child and the 6-year-old children had more inwardorientation problems than the 4-year-old children. When the other studies carried out with the same 
measurement tool; Yaşar Ekici (2014) concluded that there is no difference in the problem behaviors of children depending on the age of the child. When the results related to the age status of the child are examined in different researches about problem behaviors, similar results have been reached in the studies of Kargı and Erkan (2004), Kanlıkılıçer (2005), Şehirli (2007), Olcay (2008), and Memetali (2014).

When the relational results of the study are examined, it is seen that there is a negative relationship between conflict and positive relationship. According to these results, the higher the level of conflict, the lower the positive relationship level. When the results of regression analysis are examined, it is seen that the conflict positively predicts the inward behaviors. When the results of the research are examined in general; According to the scores obtained from the child-parent relationship scale, there was no difference depending on the age and working status of the mother, but there was a difference depending on the education level of the mother. It was seen that there was a difference in the childmother relationship according to the gender of the child, but there was no differentiation according to the age of the children. It was observed that both the outward and inward behaviors exhibited by the children differed according to their mothers' age and level of education, but there was no difference depending on the working status of the mother. The gender and age of the child also showed a difference in both outward and inward oriented behaviors.

\section{Suggestions}

This research was carried out with kindergartens of the public primary schools of the Ministry of National Education, children attending independent kindergartens and their mothers. The same research can be done with children of different age groups and their families in state, private and foundation schools. The problem behaviors and mother-child relationship discussed in the research can be examined with other variables (mother's profession, number of siblings, birth order, etc.). For similar studies on mother-child relations, it is suggested that not only mother-child relations, but also fatherchild, mother-father-child relationships and families with different demographic characteristics such as different socio-economic levels, separation of rural and urban life. This study is limited to the mothers' answers to the questions. Observation-based qualitative and longitudinal studies can be conducted with a certain number of children. In this way, the problem behaviors of children and the situation of the families can be examined in a more detailed way. The scales used in the study can be applied to mothers and teachers simultaneously and the differences can be evaluated. It may be suggested that the sample group participating in the study or participating in this research should organize trainings covering effective communication ways with children, especially ways to develop quality and positive relations with children with problem behaviors.

\section{References}

Akgün, E., \& Yeşilyaprak, B. (2010). Çocuk ana baba ilişki ölçeği Türkçe formunun geçerlik ve güvenirlik çalışması. Balkesir Üniversitesi Sosyal Bilimler Ensitütüsü Dergisi, 13(24), 44-53. https://dergipark.org.tr/tr/pub/baunsobed/issue/50235/647940

Alisinanoğlu, F., \& Kesicioğlu, O. S. (2010). Okul öncesi dönem çocuklarının davranış sorunlarının çeşitli değişkenler açısından incelenmesi (Giresun ili örneği). Kuramsal Eğitim Bilim Dergisi, 3(1), 93110. https://dergipark.org.tr/tr/pub/akukeg/issue/29340/313969 
Alisinanoğlu, F.(2003). Çocukların denetim odağı ile algıladıkları anne tutumlar arsındaki ilişkinin incelenmesi(Çocukların denetim odağı ile anne tutumları). Türk Ĕ̆itim Bilimleri Dergisi, 1(1),114. https://dergipark.org.tr/tr/download/article-file/256464

Alpgan, Ö. (2018).Gelişimsel yetersizliği olan çocuklarm ebeveynlerinin aile yaşam kalitesi düzeyinin çocuk anne-baba ilişkisi üzerine etkisinin incelenmesi (Master's thesis). Retrieved from CoHE Thesis Center (Thesis No: 515861).

Aslan, N. (2018). 60-72 aylık çocukların empati becerilerinin anne çocuk ilişkisi açısından incelenmesi (Master's thesis). Retrieved from CoHE Thesis Center (Thesis No: 524529).

Avşaroğlu, S. (2012). Aile içi ilişkiler ve iletişim. İçinde. A. Kaya (Ed.) Kişiler arası iliş̧iler ve etkili iletişim (s.250-270). Ankara: Pegem Akademi.

Aydoğan Y., \& Gülümser Akduman G. (2016). Çocuk ruh sağlığı. Ankara: Eğiten Kitap.

Bailey, J. A., Hill, K. G., Oesterle, S., \& Hawkins, J. D. (2009). Parenting practices and problem behavior across three generations: Monitoring, harsh discipline, and drug use in the intergenerational transmission of externalizing behavior. Developmental Psychology, 45(5), 1214-1226. DOI: 10.1037 / a0016129.

Bakırcıoğlu, R. (2007). Çocuk ruh sağlığı ve uyum bozuklukları. Ankara: AnıYayıncılık.

Bartan, M., \& Tezel Şahin, F. (2012) Ebeveyn çocuk ilişkisi envanterinin 60-72 Aylık çocukların anne babalarına uyarlanması. Dumlupınar Üniversitesi Sosyal Bilimler Enstitüsü Dergisi, 34, 185-200. https://dergipark.org.tr/tr/download/article-file/55826

Çakıcı, S. (2006). Alt ve üst sosyoekonomik düzeydeki ailelerin aile işlevlerinin, anne-çocuk ilişkilerinin ve aile işlevlerinin anne-çocuk ilişkilerine etkisinin incelenmesi (Master's thesis). Retrieved from CoHE Thesis Center (Thesis No: 187659).

Çetintaş, S. (2015). 5 yaş çocuklarında görülen davranış problemleri ile annelerin çocuklarına uyguladıkları disiplin yöntemleri arasındaki ilişkinin incelenmesi (Master's thesis). Retrieved from CoHE Thesis Center (Thesis No: 388187).

Driscoll, K., \& Pianta, R. C. (2011). Mothers and fathers perceptions of conflict and closeness in parentchild relationships during early childhood. Journal of Early Childhood \& Infant Psychology, 7(1), 124. https://psycnet.apa.org/record/2013-00755-001

Dursun, A. (2010). Okul öncesi dönemdeki çocukların davranış problemleriyle anne-baba tutumları arasındaki ilişkinin incelenmesi (Master's thesis). Retrieved from CoHE Thesis Center (Thesis No: 265502).

Eratay, E. (2011). Okul öncesi çocuklarında davranış problemleri. Education Sciences, 6(3), 2347-2362.

Gültekin Akduman, G., \& Türkoğlu D. (2013). Okul öncesi dönem çocuğu olan babaların babalık rollerini algılamaları ile çocuklarının davranış problemleri arasındaki ilişkinin incelenmesi. Uluslararası Aile Çocuk ve Eğitim Dergisi, 1(1), 17. https://www.idealonline.com.tr/IdealOnline/lookAtPublications/documentIngredient.xhtml?uI $\underline{\mathrm{d}=3614 \& \text { ioM=IournalIssue. }}$. 
Güven, E. (2013). Çocuğun davranış sorunları ile algıladı̆̆̆ anne baba çatışması arasındaki ilişkiler: duygu sosyalleştirmenin aracı rolü (Master's thesis). Retrieved from CoHE Thesis Center (Thesis No: 330324).

Kanlıkılıçer, P. (2005). Okul öncesi davranış sorunları tarama ölçeği: geçerlik güvenirlik çalışması (Master's thesis). Retrieved from CoHE Thesis Center (Thesis No: 188733).

Karg1, E., \& Erkan, S. (2004). Okul öncesi dönem çocuklarının sorun davranışlarının karşılaştırılması. Hacettepe Üniversitesi Eğitim Fakültesi Dergisi, 34(2), 263-275. http://www.efdergi.hacettepe.edu.tr/shw artcl-808.html

Kılıç, N. (2016). 5-6 yaş çocuklarının sosyal beceri ve problem davranışları ile oyun davranışları arasındaki ilişkinin incelenmesi (Master's thesis). Retrieved from CoHE Thesis Center (Thesis No: 440428).

Kılıçarslan, F. (2006). Çocuk ve aile sorunlarının terapi ile tedavisi. Ankara: Nobel.

Kök, E. E. (2017). Anaokuluna devam eden çocukların ebeveynleri ile ilişkilerinin çocukların oyun davranışlarına yansimasinin incelenmesi (Master's thesis). Retrieved from CoHE Thesis Center (Thesis No: 454884).

Köyceğiz, M. (2017). Okul öncesi dönem çocuğu olan ebeveynlerin iletişim becerileri ve çatışma eğilimleri ile çocuklarının sosyal becerileri ve problem davranışları arasındaki ilişkinin incelenmesi (Master's thesis). Retrieved from CoHE Thesis Center (Thesis No: 461532).

Kurt, F. K. (2015). Anasınıfına devam eden 60-72 aylık çocukların duygusal beceri düzeylerinin ve problem davranışlarının incelenmesi (Master's thesis). Retrieved from CoHE Thesis Center (Thesis No: 437089).

Livanage, K. C., Prince, M. J., \& Scott, S. (2003). Mother-child joint activity and behavior problems of preschool children. Journal of Child Psychology Psychiatry, 44(7), 1037- 1048. DOI: 10.1111 / 1469 7610.00188 .

Memetali, S. (2014). Batı Trakya örnekleminde okul öncesi ve anaokulu davranış ölçeğinin geçerlilik ve güvenirlik çalışması (Master's thesis). Retrieved from CoHE Thesis Center (Thesis No: 370377).

Merrell, K. W. (2003). Behavioral, social and emotional assessment of childrenand adolescents (2. edition). New Jersey: Lawrence Erlbaum Associates.

Olcay, O. (2008). Bazı kişisel ve ailesel değişkenlere göre okul öncesi çocukların sosyal yetenekleri ve problem davranımlarmm analizi (Master's thesis). Retrieved from CoHE Thesis Center (Thesis No: 219202).

Özbey, S. (2009). Anaokulu ve anasınıfı davranış ölçeğinin geçerlik güvenirlik çalışması ve destekleyici eğitim programinin etkisinin incelenmesi (Doctoral dissertation). Retrieved from CoHE Thesis Center (Thesis No: 227837).

Özbey, S., \& Alisinanoğlu, F. (2009). Okul öncesi eğitim kurumuna devam eden 60-72 aylık çocukların problem davranışlarının bazı değişkenlere gore incelenmesi. Uluslararası Sosyal Araştırmalar Dergisi,2(6),493-517. https://www.sosyalarastirmalar.com/cilt2/sayi6pdf/ozbey_alisinanoglu.pdf 
Profeta, Y. (2002). Çocu ğun davranış problemleri ile ebeveyn çatışmasını algılayışı arasındaki ilişki (Master's thesis). Retrieved from CoHE Thesis Center (Thesis No: 135250).

Rathus, S. A. (2006). Childhood: Voyages in development. Belmont, CA: Thomson/Wadsworth.

Sargın, N. (2001). Çocuk ruh să̆lı̆̆ı. Ankara: Nobel Yayın Dağıtım.

Sayg1, D. (2011). Ebeveyn - Çocuk İlişkisi Ölçeği'nin Türkçe' ye uyarlanması ve anne-çocuk ilişkisinin bazı değişkenler açısından incelenmesi (Master's thesis). Retrieved from CoHE Thesis Center (Thesis No: 298627).

Saygı, D., \& Uyanık Balat, G. (2013). Anasınıfına devam eden çocuğu olan annelerin çocukları ile ilişkilerinin incelenmesi. International Journal of Human Science, 10(1), 844-862. https://www.jhumansciences.com/ojs/index.php/IJHS/article/view/2521/1094

Selimoğlu, H. (2014). İşitsel muhakeme ve işlem becerilerinin ebeveynlerine ait değişkenler açısından incelenmesi (Master's thesis). Retrieved from CoHE Thesis Center (Thesis No: 377653).

Seven, S. (2007). Ailesel faktörlerin altı yaş çocuklarının sosyal davranış problemlerine etkisi. Kuram ve Uygulamada Ĕ̆itim Yönetimi, 51(1), 10-15. https://dergipark.org.tr/tr/download/article$\underline{\text { file/108312 }}$

Şehirli, N. (2007). Çocuk davranışların değerlendirme ölçeğinin geliştirilmesi ve bazı değişkenlere göre incelenmesi (Master's thesis). Retrieved from CoHE Thesis Center (Thesis No: 207058).

Taner-Derman, M., \& Başal, H. A. (2013). Okulöncesi çocuklarında gözlenen davranış problemleri ile ailelerinin anne-baba tutumları arasındaki ilişki. Amasya Üniversitesi Eğitim Fakültesi Dergisi, 2(1), 115-144 https://dergipark.org.tr/tr/download/article-file/19604

Tarkoçin, S., \& Tuzcuoğlu, N. (2014). Okul öncesi eğitim kurumuna devam eden 48-66 aylık çocukları olan ebeveynlerin çocuklarıyla iletişim kurma düzeyleri ve davranış sorunları arasındaki ilişkinin bazı değişkenler açısından incelenmesi. Akademik Sosyal Araştırmalar Dergisi, 2(8), 339354. http://dx.doi.org/10.16992/ASOS.433

Tekbıyık, A. (2015). İlişkisel araştırma yöntemi, M. Metin (Ed). Ĕ̆itimde bilimsel araştırma yöntemleri, (99114). Ankara: Pegem Akademi

Tok, S . (2001). Aile içi iletişim ve çocuk. Çă̆daş Ĕ̆gitim Dergisi, 279(9), 34-39.

Turan Güven, T. (2018). 48-60 aylık çocuklarm sosyal becerilerinin ve problem davranışlarının ebeveynleri tarafindan değerlendirilmesi (Master's thesis). Retrieved from CoHE Thesis Center (Thesis No: 514467).

Wilmshurst, L. (2005). Essentials of child psychopathology. New Jersey: JohnWiley \& Sons Inc.

Wolff, S. (2009). Problem Çocuklar: Stres Altındaki Çocukları Tedavi Etme Yöntemleri (A, Oral \& S, Kara, Çev) İstanbul: Say Yayınları.

Yaşar Ekici, F. (2013). Okul öncesi eğitim kurumlarındaki aile katılım çalışmalarına katılan ve katılmayan ailelerin çocuklarının sosyal beceri ve problem davranışlar açısından karşılaştırılması (Doctoral dissertation). Retrieved from CoHE Thesis Center (Thesis No: 349957). 
Yaşar Ekici, F. (2014). Aile özellikleri ile okul öncesi eğitime devam eden çocukların problem davranışları arasındaki ilişkinin incelenmesi. Akademik Sosyal Araştırmalar Dergisi, 2(2), 70-108. DOI: 10.16992/ASOS.167

Yavuzer, H. (1999). Ana-baba ve çocuk. İstanbul: Remzi Kitabevi.

Yörükoğlu, A. (1998). Çocuk ruh sağlı̆̆ı. İstanbul: Özgür Yayınları

Yüksek Usta, S. (2014). Okul öncesi dönem çocuklarda davranış problemlerini anne - çocuk ve öğretmen çocuk ilişkileri açısından incelenmesi (Master's thesis). Retrieved from CoHE Thesis Center (Thesis No: 383789). 